\title{
PERSEPSI MAHASISWA TENTANG BANK SYARIAH TERHADAP KEPUTUSAN MENABUNG DI PERBANKAN SYARIAH
}

(Studi Kasus Pada Mahasiswa Sekolah Tinggi Ilmu Ekonomi Muhammadiyah Jambi)

\author{
Wella Sandria \\ Sekolah Tinggi Ilmu Ekonomi Muhammadiyah Jambi \\ wella_sandria@yahoo.com
}

\begin{abstract}
Islamic Bank is a bank whose operating system uses sharia principles. Currently many terms are given to refer to Islamic Bank entities other than Islamic Banks themselves, namely Banks Without Riba (La Riba Bank), and Islamic Banks (Shari'a Bank) or banks based on sharia principles. Students are the right target for Islamic banking to increase savings growth. Savings are needed in students, not only students who come from within the city but also come from outside. The purpose of this study is to find out how the Economic School of Muhammadiyah Jambi students' 'perceptions about Islamic banking, and how strong the influence of students' perceptions on the decision to save in Islamic banks. The theories used are perception theory by Michael W. Levine \& Shefner and the factors that influence consumer decisions by Mowen and Michael. The results of this study indicate that the perception of students of the Economic School of Muhammadiyah Jambi regarding sharia banking services in Jambi is very positive, indicated by the level of their understanding of Islamic banking services. They believe well that saving in Islamic banks is more beneficial than in conventional banks. However, the decision to save is still in conventional banks. There are only $24.6 \%$ of students who have savings in Islamic banks. The remaining $75.4 \%$ do not have savings in Islamic banks.
\end{abstract}

Keywords: Islamic Banks, Conventional Banks, Riba, Savings, Consumers, Banking Services, Interest

\begin{abstract}
Abstrak
Bank Syariah adalah bank yang sistem operasinya menggunakan prinsip Syariah. Saat ini ada banyak terminology yang digunakan untuk merujuk bank syariah seperti bank tanpa riba (bank la riba), dan bank syariah (bank syariah) atau bank berdasarkan prinsip syariah. Mahsiswa adalah target yang tepat bagi perbankan Islam untuk meningkatkan pertumbuhan produk dan layanan. Tabungan sangat dibutuhkan mahasiswa, tidak hanya mereka yang datang dari dalam kota tetapi juga dari luar. Tujuan dari penelitian ini adalah untuk mengetahui persepsi mahasiswa Sekolah Tinggi Ilmu Ekonomi Muhammadiyah Jambi tentang perbankan syariah, persepsi persepsi mahasiswa tentang keputusan menabung di bank syariah. Penelitian ini menggunakan teory Michael W. Levine \& Shefner dan faktor-faktor yang mempengaruhi keputusan konsumen oleh Mowen dan Michael. Penelitian ini penulis menggunakan jenis data primer dimana data diperoleh langsung dari sumbernya, diamati dan dicatat yang berasal dari kuisinoner, wawancara, observasi, dan dokumentasi. Sedangkan data sekunder adalah data yang diambil secara tidak langsung dari sumbernya, seperti data dokumen dan lainnya. Data yang diperoleh dianalisis dengan menggunakan software SPSS versi 23.0. Data kuesioner dianalisis secara kuantitatif dengan menggunakan analisis dekriptif untuk mengetahui berapa besar persentase pilihan jawban dari setiap pertanyaan.

Hasil penelitian ini menunjukkan bahwa bahwa persepsi mahasiswa STIE Muhammadiyah Jambi terhadap jasa perbankan syariah di Jambi sangat positif ditunjukkan dengan tingkap pemahaman mereka akan jasa perbankan syariah. Hal ini ditujukkan dengan
\end{abstract}


pemahaman mereka yang baik terhadap perbedaan antara perbakan konvensional dan perbankan syariah. Mereka juga telah meyakini bahwa pernbankan syariah yang ada saat ini telah menjalankan manajemen dan produk-produk mereka secara syar'i. Bahkan mereka meyakini dengan baik bahwa menabung di bank syariah lebih memberi manfaat dibandingkan dengan di bank konvensional. Keputusan menabung mahasiswa STIE Muhammadiyah Jambi masih ada pada bank-bank konvensional. Hanya terdapat 24,6\% mahasiswa yang memiliki tabungan di bank-bank syariah. Selebihnya $75,4 \%$ belum memiliki tabungan di bank syariah.

Kata kunci: Bank Syariah, Bank Konvensional, Riba, Tabungan, Konsumen, Layanan Perbankan, Bunga

\section{PENDAHULUAN}

Bank Islam (Islamic Bank) adalah bank yang sistem pengoperasiannya menggunakan prinsip-prinsip syariah. Saat ini banyak istilah yang diberikan untuk menyebut entitas Bank Islam selain Bank Islam itu sendiri, yaitu Bank Tanpa Riba (La Riba Bank), dan Bank Syariah (Shari'a Bank) atau bank berdasarkan prinsip syariah.

Di dunia internasional, bank syariah dilatarbelakangi dengan adanya Konferensi Negara-Negara Islam sedunia pada tanggal 21-27 April 1969. Pertemuan beberapa negara muslim ini memberi dampak positif berupa perkembangan bank syariah atau bank Islam yang ditengarai lebih dari 200 lembaga keuangan dan investasi syariah yang berkembang sejak tahun 1975. Pada tahun tersebut, perkembangan sistem ekonomi syariah secara empiris diakui dengan lahirnya Islamic Development Bank (IDB). Sementara di Indonesia, PT. Bank Muamalat Indonesia, Tbk (BMI) memulai perjalanan bisnisnya sebagai bank syariah pertama di Indonesia pada 1 November 1991 atau 24 Rabi'us Tsani 1412 H. Pendirian BMI digagas oleh Majelis Ulama Indonesia (MUI), Ikatan Cendekiawan Muslim Indonesia (ICMI) dan pengusaha muslim yang kemudian mendapat dukungan dari Pemerintah Republik Indonesia. Sejak resmi beroperasi pada 1 Mei 1992 atau 27 Syawal 1412 H, BMI terus berinovasi dan mengeluarkan produk-produk keuangan. Sistem operasional BMI mengacu pada PP No.7 tahun 1992 tentang bank bagi hasil. Pada tahun 1998, disahkan Undang Undang RI No.10 Tahun 1998 tentang perubahan atas Undang Undang No.7 Tahun 1992 tentang perbankan. Secara legal, perbankan syariah telah diakui sebagai subsistem perbankan nasional.

Ditengah dinamika tumbuh dan berkembangnya bank syariah, pada tahun 1997 terjadi krisis ekonomi datang menerjang yang memporak-porandakan sistem perbankan nasional. Mulai bulan Juli 1997 sampai dengan 13 Maret 1999, pemerintah menutup 55 bank, mengambil alih 11 bank dan 9 bank lainnya dibantu melakukan rekapitalisasi. Pada Oktober 2001, sebagaimana laporan Majalah Investasi (2001) terjadi lagi satu bank konvensional yang 
dibekukan atau Bank Baku Kegiatan Usaha (BBKU). Dari 240 bank sebelum krisis, kini hanya tinggal 73 bank swasta yang dapat bertahan tanpa bantuan pemerintah (Sumitro, 1997).

Di Indonesia terdapat dua jenis bank yaitu bank konvensional dan bank syariah. Upaya pengembangan bank syariah tidak cukup hanya berlandaskan kepada aspek - aspek legal dan peraturan perundang-undangan tetapi juga harus berorientasi kepada pasar atau masyarakat sebagai pengguna jasa (konsumen) lembaga perbankan. Keberadaan bank (konvesional dan syariah) secara umum memiliki fungsi strategis sebagai lembaga intermediasi dan memberikan jasa dalam lalu lintas pembayaran, namun karakteristik dari kedua tipe bank (konvensional dan syariah) dapat mempengaruhi perilaku calon nasabah dalam menentukan preferensi mereka terhadap pemilihan antara kedua tipe bank tersebut. Lebih lanjut, perilaku nasabah terhadap produk perbankan (bank konvensional dan bank syariah) dapat dipengaruhi oleh sikap dan persepsi masyarakat terhadap karakteristik perbankan itu sendiri (Mustikawati, 2013).

Bank syariah mempunyai banyak keunggulan karena tidak hanya berdasarkan pada syariah saja sehingga transaksi dan aktifitasnya menjadi halal, tetapi sifatnya yang terbuka dan tidak mengkhususkan diri bagi nasabah muslim saja tetapi juga bagi nonmuslim. Hal ini membuktikan bahwa bank syariah membuka peluang yang sama terhadap semua nasabah dan tidak membedakan nasabah. Menurut Sumitro (2004), bank syariah adalah lembaga keuangan yang usaha pokoknya memberikan kredit dan jasa dalam lalu lintas pembayaran serta peredaran uang yang pengoperasiannya disesuaikan dengan prinsip Islam.

Bank syariah memiliki produk atau jasa yang tidak akan ditemukan dalam operasi bank konvensional. Prinsip - prinsip seperti musyarakah, mudharabah, murabahah, ijarah, istishna dan sebagainya tidak memuat adanya prinsip bunga seperti yang dikembangkan oleh bank konvensional. Sebagai sesuatu yang baru, keberadaan bank syariah dan produknya tentu akan menjadi suatu pilihan yang mungkin diminati dan mungkin pula tidak.

Pandangan masyarakat terhadap lembaga keuangan syariah diantaranya dapat diwakili dengan pandangan masyarakat terhadap perbankan syariah. Kesan umum yang ditangkap oleh masyarakat tentang perbankan syariah adalah (1) perbankan syariah identik dengan bank dengan sistem bagi hasil, (2) perbankan syariah adalah bank Islami. Hal ini sesuai dengan pendapat Susilo, dkk (2000), yang menjelaskan bahwa bank syariah yaitu bank yang dalam aktivitasnya, baik penghimpunan dana maupun dalam ragka penyaluran dananya memberikan dan mengenakan imbalan atas dasar prinsip syariah yaitu jual beli dan bagi hasil. Dimana faktor pertimbangan agama adalah motivator penting untuk mendorong penggunaan jasa bank 
syariah dan masyarakat non nasabah yang diberi penjelasan tentang produk/jasa perbankan syariah mempunyai kecenderungan yang kuat untuk memilih bank syariah.

Maraknya pertumbuhan dan perkembangan bank syariah tersebut di pandang sinis oleh beberapa kalangan, bahkan kalangan umat Islam sendiri. Sinisme terhadap perbankan syariah itu sendiri dapat dilihat dari kepercayaan masyarakat Islam terhadap bank syariah yang masih sangat rendah. Hal tersebut dapat dilihat dari partisipasi umat Islam dalam investasi atau perguliran modal. Sinisme tersebut tidak terlepas dari pengaruh dari ekonomi kapitalis yang sudah mendarah daging di masyarakat, terutama anggapan kapitalis bahwa tidak ada bank tanpa bunga.

Sekolah Tinggi Ilmu Ekonomi (STIE) Muhammadiyah Jambi adalah salah satu perguruan tinggi swasta di kota Jambi yang memiliki banyak mahasiswa. Mahasiswa merupakan sasaran yang tepat bagi perbankan syariah untuk memperbesar pertumbuhan tabungan. Tabungan sangat dibutuhkan dalam kalangan mahasiswa, tidak hanya mahasiswa berasal dari dalam kota saja melainkan juga berasal dari luar kota. Salah satu jasa tabungan yang banyak dibutuhkan oleh mahasiswa perantauan atau luar kota adalah tabungan untuk menyimpan uang bulanan.

Pengetahuan tentang perbankan syariah dapat diperoleh melalui jalur pendidikan formal dan informal. Dalam pendidikan formal pengetahuan tentang perbankan syariah dapat diperoleh dalam bentuk mata pelajaran atau mata kuliah tentang perbankan dan lembaga keuangan. Selain itu, pengetahuan tentang perbankan syariah juga dapat diperoleh dari pendidikan informal dalam bentuk interaksi dengan orang tua, teman sebaya, masyarakat, dan media (televisi, radio, majalah, koran, atau buku - buku tentang perbankan syariah. Adanya pengetahuan yang dimiliki, maka dapat menimbulkan adanya persepsi bagi seseorang. Stanton dalam Setiadi (2003) menyatakan bahwa, persepsi didefinisikan sebagai makna yang kita pertalikan berdasarkan pengalaman masa, stimuli (rangsangan-rangsangan) yang kita terima melalui lima indera. Menurut Lucas dan Brit dalam Nurpratama (2014) mengemukakan bahwa aspek - aspek minat terdiri dari Perhatian (Attention), Ketertarikan (Interest), dan Keinginan (Desire).

Pada dasarnya perilaku mahasiswa terhadap perbankan syariah sama saja dengan perilaku nasabah lainnya, tetapi nasabah mahasiswa memiliki kecenderungan minat menabung yang besar karena usia mereka yang masih muda dan rasa ingin tahu yang besar. Namun demikian perlu lihat secara ilmiah melalui penelitian ini bagaimana persepsi mahasiswa 
Sekolah Tinggi Ilmu Ekonomi Muhammadiyah Jambi tentang perbankan syariah, dan seberapa kuat pengaruh persepsi mahasiswa Sekolah Tinggi Ilmu Ekonomi Muhammadiyah Jambi terhadap keputusan menabung di bank syariah.

Penelitian ini diharapkan dapat memberikan dampak positif bagi berbagai stakeholder. Bagi masyarakat, hasil penelitian ini diharapkan dapat dijadikan bahan masukan dalam memilih dan memutuskan untuk menabung dan berinvestasi di bank syariah. Bagi perbankan syariah, hasil penelitian ini diharapkan dapat dijadikan sebagai bahan masukan dalam membentuk persepsi nasabah terhadap bank syariah dan meningkatkan kualitas jasa pelayanan bank syariah yang amanah. Bagi akademisi, hasil penelitian ini diharapkan dapat memberi manfaat teoritis bagi pengembangan keilmuan dan pengetahuan mengenai perbankan syariah.

\section{METODE PENELITIAN}

penelitian ini penulis menggunakan jenis data primer dimana data diperoleh langsung dari sumbernya, diamati dan dicatat yang berasal dari kuisinoner, wawancara, observasi, dan dokumentasi. Sedangkan data sekunder adalah data yang diambil secara tidak langsung dari sumbernya, seperti data dokumen dan lainnya. Data yang diperoleh dianalisis dengan menggunakan software SPSS versi 23.0. Data kuesioner dianalisis secara kuantitatif dengan menggunakan analisis dekriptif untuk mengetahui berapa besar persentase pilihan jawban dari setiap pertanyaan. Data kualitatif hasil dari wawancara langsung kepada partisipan dianalisis dengan membuat transkrip wawancara, menuliskan secara cermat data dan informasi yang didapatkan dan direduksi.

Berbagai persoalan muncul ketika seseorang harus memutuskan apakah harus memilih menabung di bank syariah atau bank konvensional. Selaras dengan permasalahan diatas, maka hipotesis penelitian ini adalah: Sejauh mana pengetahuan dan pemahaman mahasiswa STIE Muhammadiyah Jambi dapat membentuk persepsi mereka mnegenai bank syariah? Sejauh mana persepsi mahasiswa STIE Muhammadiyah Jambi tentang bank syariah dapat mempegaruhi keputusan mereka dalam menabung di bank syariah?

\section{HASIL DAN PEMBAHASAN}

Persepsi seseorang dapat timbul dari pengalaman yang telah diperolehnya, baik yang dilakukan sendiri maupun kesan dari orang lain. Akumulasi dari persepsi akan mampu membentuk suatu opini asumsi atau kesimpulan tentang sesuatu yang dialaminya. Definisi persepsi menurut Michael W. Levine \& Shefner (2007) yaitu: "Persepsi merupakan cara dimana kita menginterpretasikan informasi yang dikumpulkan (di proses) oleh indera”. 


\section{A. Faktor - Faktor yang Mempengaruhi Keputusan Konsumen}

Faktor yang mempengaruhi keputusan konsumen (Mowen dan Michael : 2002), yaitu:

\section{a. Faktor Budaya}

Budaya adalah faktor mendasar dalam pembentukan norma - norma yang dimiliki seseorang yang kemudian membentuk atau mendorong keinginan dan perilakunya menjadi seseorang konsumen.

1) Nilai. Adalah norma yang di anut masyarakat.

2) Persepsi. Adalah cara pandang terhadap sesuatu.

3) Preferensi. Rasa lebih suka pada sesuatu dibandingkan dengan yang lainya.

4) Behavior. Adalah perilaku seseorang dalam mengkonsumsi suatu produk.

\section{b. Faktor Sosial}

Anggota keluarga dapat sangat mempengaruhi perilaku pembeli. Keluarga adalah organisasi pembelian kosumen paling penting dalam masyarakat, dan pengaruh tersebut telah diteliti secara ekstensif.

1) Faktor Pembeli. Keputusan seorang pembeli juga dipengaruhi oleh karakteristik pribadi seperti umur pembeli dan tahap siklus hidup, pekerjaan, situasi ekonomi, gaya hidup, serta kepribadian dan konsep diri.

2) Reference Group. Adalah kelompok yang mempengaruhi anggotanyadalam membuat keputusan pembelian sesuatu barang dan jasa meskipun ada pengecualian pada sebagian orang.

\section{c. Faktor Teknologi}

1) Transportasi Pribadi. Misalnya mobil dan motor bertambah dari tahun ke tahun berikut kecanggihan teknologinya yang bertambah dari tahun ke tahun.

2) Audio Visual. Telah menjadi produk pemikat perorangan sejak puluhan tahun lalu, baik untuk dinikmati oleh diri sendiri maupun untuk keluarga.

3) Kemajuan Informasi, Teknologi dan Komunikasi. Seperti internet dan seluler kemajuan komputer pribadi, telepon seluler meningkatkan pasar hardware.

4) Faktor Psikologis. Meliputi pilihan - pilihan seseorang dalam membeli dipengaruhi oleh empat faktor psikologi yang penting, yaitu : motivasi, persepsi, pengetahuan dan keyakinan serta sikap. 


\section{B. Persepsi Mahasiswa Sekolah Tinggi Ilmu Ekonomi (STIE) Muhammadiyah Jambi Tentang Perbankan Syariah}

Persespi mahasiswa Sekolah Tinggi Ilmu Ekonomi (STIE) Muhammadiyah terhadap perbankan syariah dapat dilihat dari pandangan umum mereka terhadap perbankan tersebut. Di STIE Muhammadiyah Jambi terdapat beberapa program studi yaitu Manajemen dan Ekonomi Pembangunan. Masing-masing jurusan memiliki persepsi sendiri. Namun, secara umum mereka mengetahui dengan pasti bahwa di Indonesia terdapat dua jenis perbankan yaitu bank konvensional dan bank syariah. Kedua jurusan ini hampir 100\% mengetahui hal ini.

Data menunjukkan bahwa dari total sampel yang diambil keseluruhan mahasiswa program studi pembangunan mengetahui keberadaan perbankan syariah di Indonesia. Mahasiswa Prodi Pembangunan 100\% mengetahui perbankan syariah dan mahasiswa Prodi Manajemen terdapat 1,6\% yang masih belum mengetahuinya.

Pengetahuan mahasiswa yang baik ini tentunya sangat dipengaruhi oleh desain kurikulum yang ada di sekolah tinggi ini. Sebanyak 78\% dari total sampel yang diambil dari dua jurusan ini menyatakan pernah mendapatkan mata kuliah perbankan atau lembaga keuangan. Hanya 22\% saja yang belum mendapatkan mata kuliah ini.

Jika dicermati lebih lanjut, sebagian besar mereka yang belum mengambil mata kuliah ini adalah mahasiswa semester dua, sementara untuk semester empat ke atas sudah 100\% mengambil. Bagi mereka yang belum mengambil mata kuliah ini pada semester dua diperkirakan menyangkut dengan jumlah sks yang mereka miliki menyesuaikan indeks prestasi (IP) yang di dapat. Atau juga, mereka yang sudah mengambil mata kuliah ini terlebih dahulu dengan mengambil mata kuliah ke atas atau semester lanjut.

Pengetahuan mahasiswa STIE Muhammadiyah Jambi yang membentuk persepsi mereka terhadap perbankan syariah tidak hanya dibentuk melalui kelas formal yang mereka dapatkan melalui mata kuliah yang disedikan tetapi juga dengan mengikuti berbagai seminar, pelatihan, sosialisasi dan aktivitas sejenisnya.

Data menunjukkan terdapat bahwa kedua mahasiswa program studi yang menjadi sampel penelitian menunjukkan separuh dari mereka belum pernah mengikuti seminar, pelatihan, sosialisasi atau kegiatan-kegiatan lain yang menyangkut dengan perbankan syariah. Mahasiswa Program studi Pembangunan menyatakan bahwa 16,4\% belum pernah ikut. Begitu juga prodi Manajemen 41,0\% belum pernah ikut sama sekali. Jika digabungkan untuk ke dua 
prodi ini maka lebih dari setengah $(57,4 \%)$ mahasiswa STIE Muhammadiyah Jambi belum tersentuh oleh kegiatan ekstra kampus pengenalan tentang perbankan syariah.

Penelitian ini mengisyaratkan tantangan dan peluang baik bagi kampus STIE Muhammadiyah Jambi maupun perbankan syariah sendiri. Persepsi positif tidak akan terbentuk jika para mahasiswa tidak dikenalkan dan dipahamkan tentang perbankan syariah. Ilmu pengetahuan mereka tidak hanya bisa ditransfer melalui kelas tetapi juga sangat penting ditambah dengan mengikuti berbagai aktivitas luar kampus seperti seminar, pelatihan, atau sosialisasi. Angka 57,4\% mengindikasikan bahwa masih ada 42,6 \% masih menjadi tantangan dan peluang bagi stakeholder yang berkepentingan.

Angka ini ternyata tidak jauh berbeda bila dilihat dari asal daerah mereka. Sebagian besar dari mereka tidak pernah mengikuti kegiatan berupa seminar, pelatihan atau sosialisasi tentang perbankan syariah. Bahkan, para mahasiswa yang berasal dari Jambi saja yang notabene tinggal di kota, masih belum tersentuh dengan kegiatan ini. Data menunjukkan bahwa $34,4 \%$ menyatakan tidak pernah.

Namun demikian, ketika ditanya 'apakah mereka mengenal nama-nama bank syariah di Indoneisa?', sebanyak 90,2\% dari dua progaram studi yang ada di STIE Muhammadiyah Jambi menyatakan mengenal. Tidak sampai $10 \%$ tepatnya 9,8\% yang menyatakan tidak. Mereka juga mampu menyebutkan beberapa nama bank syariah yang ada di Indonesia.

Sebagaimana diketahui, menurut syariahcenter.wordpress.com, terdapat paling tidak 11 nama bank umum syaraiah, sebagaimana berikut.

\section{BANK UMUM SYARIAH (BUS)}

1. PT. Bank Syariah Mandiri

2. PT. Bank Syariah Muamalat Indonesia

3. PT. Bank Syariah BNI

4. PT. Bank Syariah BRI

5. PT. Bank Syariah Mega Indonesia

6. PT. Bank Jabar dan Banten

7. PT. Bank Panin Syariah

8. PT. Bank Syariah Bukopin

9. PT. Bank Victoria Syariah

10. PT. BCA Syariah

11. PT. Maybank Indonesia Syariah 
Persepsi mahasiswa terhadap perbankan syariah sebenarnya terletak pada pemahaman dasar dalam membedakan antara bank konvensional dan bank syariah. Pada penelitian ini, sebagaimana hasil isian kuisioner dan wawancara mendalam terhadap responden, didapati jawaban mereka yaitu bunga dan riba. Berikut ini jawaban kualitatif yang mereka berikan atas pertanyaan, 'Menurut Anda, apa perbedaan mendasar antara bank konvensional dan bank syariah?'

Responden 1: Pada prinsip dasar layanan (bank syariah) yang disunnahkan”.

Responden 10: "Lebih pada pemanfaatannya. Kalau bank syariak tidak berbunga, sedangkan konvensional sebaliknya".

Responden 17: "Bank konvensional banyak riba, sedangkan syariah tidak".

Responden 19: 'Bank Konvensional menghasilkan bunga. Sedangkan bank syariah tidak menghasilkan bunga'.

Data ini menunjukkan dengan jelas bahwa mahasiswa STIE Muhammadiyah telah memahami dengan baik perbedaan antara bank konvensional dan bank syariah. Pemahaman dasar ini kemudian akan sangat berpengaruh terhadap keputusan mereka untuk menggunakan kedua jenis bank tersebut.

\section{Pengaruh Persepsi Mahasiswa Sekolah Tinggi Ilmu Ekonomi (STIE) Muhammadiyah Jambi Terhadap Keputusan Menabung di Bank Syariah.}

Keputusan untuk menggunakan jasa perbankan sepenuhnya ada di tangan konsumen. Begitu juga halnya dengan pilihan apakah menggunakan bank konvensional atau bank syariah di kalangan mahasiswa STIE Muhammadiyah Jambi sepenuhnya merupakan keputusan mutlak mereka. Berikut ini adalah data statistik penggunaan bank konvensional di kalangan mahasiswa STIE Muhammadiyah Jambi.

Lebih dari separuh (50,8\%) mahasiswa STIE Muhammadiyah Jambi memiliki tabungan di bank konvensional. Dalam pengumpulan data melalui kuisioner dan wawancara mendalam diketahui pula bahwa mereka menggunakan jasa perbankan salah satu dari nama-nama bank konvensional berikut ini. Nama-nama bank konvensional di Indonesia yang banyak digunakan oleh mahasiswa STIE Muhammmadiyah Jambi adalah Bank Mandiri, Bank Negara Indonesia (BNI), Bank Rakyat Indonesia (BRI), Bank Tabungan Negara (BTN), Bank Central Asia (BCA), dan Bank 9 Jambi.

Begitu juga halnya dalam menggunakan jasa perbankan syariah. Mahasiswa STIE Muhammadiyah Jambi memiliki keputusan tersendiri untuk menjatuhkan pilihan mereka. Data 
statistik berikut ini menggambarkan bahwa tidak semua mahasiswa mau mempercayakan tabungan mereka di bank-bank syariah yang terdapat di Kota Jambi. Jika dirinci, dari dua jurusan yang menjadi sampel penelitian ini, mahasiswa Program Studi Pembangunan hanya berjumlah 6,6\% yang memiliki tabungan di bank syariah. Jumlah ini jauh lebih rendah dibandingkan dengan Program Studi Manajemen yang mencapai 18,0\%.

Secara keseluruhan sepertiga dari mereka ternyata tidak memiliki tabungan bank syariah. Sebanyak $75,4 \%$ menyatakan tidak, dan hanya $24,6 \%$ yang memiliki tabungan bank syariah.

Hal ini tentu menjadi tantangan bagi perbankan syariah di Jambi untuk menggarap pasar mahasiswa. Jumlah 75,4\% adalah gambaran pasar yang masih sangat luar untuk direbut. Sebenarnya para mahasiswa sudah memiliki landasan pemahaman yang kuat antara bank konvensional dan bank syariah. Keputusan mereka untuk menabung tentu saja juga dipengaruhi oleh berbagai faktor yang tidak hanya persoalan pemahaman semata. Faktor-faktor teknis seperti kemudahan dalam bertransaksi, layanan dalam pemberian jasa, keunggulan produk-produk yang diberikan, merupakan faktor-faktor yang sangat berpengaruh terhadap keputusan mereka.

Data di atas menunjukkan bahwa pilihan mereka memang masih banyak pada bank konvensional walaupun dengan perbedaan yang tidak signifikan. Sebanyak 57,4\% mereka memilih untuk menabung di bank syariah dan 42,6\% mereka menggunakan jasa bank syariah. Jika dirinci, mahasiswa prodi pembangunan sebanyak 9,8\% menggunakan bank syariah, dan $32,8 \%$ untuk mahasiswa prodi manajemen. Sisanya menggunakan jasa perbankan konvensional yang terdapat di kota Jambi.

Untuk mendalami persepsi mahasiswa terhadap keberadaan bank syariah, maka penelitian ini berusaha untuk membandingkan pandangan mereka terhadap dua jenis jasa perbankan yang ada dengan kata 'lebih suka mana'. Kata 'lebih suka' digali dari pengalaman mereka selama ini dalam menggunakan dua jenis jasa perbankan yang ada. Hal ini ditunjukkan dengan data bahwa sebagian besar dari mereka pernah atau sedang menggunakan kedua jenis perbankan tersebut.

Data menunjukkan bahwa mahasiswa STIE Muhammadiyah Jambi masih 'fifty-fifty' dalam menggunakan dua jenis jasa perbankan yang ada. Tidak terdapat jumlah yang terlalu kontras antara penggunaan perbankan konvensional maupun perbankan syariah. Secara keluruhan, terdapat 57,4\% mahasiswa lebih suka menabung di bank-bank konvensional dan 42,6\% lebih suka menabung di bank syariah. 
Jika dilihat lebih detail, alasan utama mereka dalam memutuskan untuk menabung di bank syariah adalah untuk menghindarkan diri dari riba bunga uang. Namun, kemudahan akses dan keunggulan produk yang mereka dapatkan juga tetap menjadi alasan mereka masih menggunakan bank konvensional.

Persepsi mahasiswa akan perbankan syariah juga dilihat dari pandangan merka terhadap pengelolaan (manjemen) juga produk yang ditawarkan. Benarkah perbankan syariah telah menerapkan manajemen dan penjualan produk mereka dengan menerapkan hukum-hukum bank syariah?

Data statistik menggambarkan bahwa 60,7\% mahasiswa STIE Muhammadiyah Jambi menganggap bahwa pengelolaan dan produk-produk bank syariah yang ada telah menerapkan hukum-hukum bank secara syar'i. Hanya terdapat 39,3\% yang berpendapat bahwa bank syariah belum sepenuhnya memenuhi aturan-aturan Islam dalam pengelolaan perbankan syariah.

Pertimbangan akhir bagi mahasiswa dalam menggunakan jasa perbankan tentunya adalah seberapa besar mereka mendapat manfaat dari jasa perbankan tersebut. Data menggambarkan bahwa Mahasiswa STIE Muhammadiyah Jambi telah merasakan manfaat menggunakan jasa perbankan syariah. Pertanyaan 'mana yang lebih memberi manfaat bagi anda' sebagai pertanyaan penegas mengapa mereka memilih bank syariah. Secara keseluruhan mereka menjawab 54,1\% bank syariah yang lebih memberi manfaat bagi mereka dan 49,9\% menjawab bank konvensional. Memang persentase ini tidak menunjukkan perbedaan yang besar tetapi cukup untuk memberikan gambaran bahwa mahasiswa STIE Muhammadiyah Jambi memiliki perspektif yang positif terhadap keberadaan perbankan syariah di Jambi.

\section{KESIMPULAN DAN SARAN}

\section{Kesimpulan}

Dari pemaparan di atas dapat disimpulkan bahwa persepsi mahasiswa STIE Muhammadiyah Jambi terhadap jasa perbankan syariah di Jambi sangat positif ditunjukkan dengan tingkap pemahaman mereka akan jasa perbankan syariah. Hal ini ditujukkan dengan pemahaman mereka yang baik terhadap perbedaan antara perbakan konvensional dan perbankan syariah.

Mereka juga telah meyakini bahwa pernbankan syariah yang ada saat ini telah menjalankan manajemen dan produk-produk mereka secara syar'i. Bahkan mereka meyakini dengan baik bahwa menabung di bank syariah lebih memberi manfaat dibandingkan dengan di bank konvensional. 
Keputusan menabung mahasiswa STIE Muhammadiyah Jambi masih ada pada bankbank konvensional. Hanya terdapat 24,6\% mahasiswa yang memiliki tabungan di bank-bank syariah. Selebihnya 75,4\% belum memiliki tabungan di bank syariah.

\section{Saran}

Dari hasil penelitian ini diharapkan kepada pihak kampus, untuk lebih memberi pemahaman tentang perbankan syariah di kalangan mahasiswa STIE Muhammadiyah Jambi, diperlukan design kurikulum yang lebih baik sehingga porsi pembelajaran tentang perbankan (syariah) dapat baik. Hal ini mengingat hasil penelitian ini menunjukkan bahwa mahasiswa merasa lebih mendapat manfaat (terutama menghindari riba dari bunga uang).

Kepada pihak perbankan syariah diharapkan lebih giat lagi mengadakan seminar, pelatihan, atau sosialisasi tentang perbankan syariah di kampus. Fasilitas (infrastruktur sperti ATM, kantor dll) yang terbatas menjadi pertimbangan mengapa mahasiswa STIE Muhammadiyah masih banyak yang belum menabung di bank syariah. Maka kualitas dan kuantitas jasa dan layanan sangat diperlukan.

\section{DAFTAR PUSTAKA}

Anshori, Abdul Ghofur. 2008. Kapita Selekta Perbankan Syariah di Indonesia. Jakarta. UII Press.

Bank Indonesia. 2005. Cetak Biru Pengembangan Perbankan Syariah Indonesia.

Ghofur, Muhammad W. 2007. Potret Perbankan Syariah Indonesia Terkini (Kajian Kritis Perkembangan Perbankan Syariah) Yogyakarta. Biruni Press.

Iyer, Easwar S. \& Kashyap Rajiv K. 2009. Noneconomic Goals of Investor. Journal of Consumer Behavior. Vol. 8 (5). pp. 225 - 237.

Mardani. 2011. Hukum Ekonomi Syariah di Indonesia. Bandung : Refika Aditama.

Mardani. 2015. Aspek Hukum Lembaga Keuangan Syariah di Indonesia. Jakarta. Kencana.

Micheal W. Levine \& Shefner. 2007. Fundamentals of Sensation and Perception.

Mowen, C. J. dan Michael, Minor. 2002. Perilaku Konsumen. Jakarta. Erlangga.

Muhammad. 2011. Manajemen Bank Syariah. Yogyakarta. UPP STIM YKPN.

Mustikawati, Indah. 2013. Pengaruh Persepsi Nasabah Tentang Suku Bunga, Promosi dan Kualitas Pelayanan Terhadap Minat Menabung Nasabah.

Nurpratama, Putra Hona. 2014. Pengaruh Product Placement Terhadap MInat Beli. 
Setiadi, Nugroho J. 2003. Perilaku Konsumen : Konsep dan Implikasi untuk Strategi dan Penelitian Pemasaran. Bandung. Prenada Media.

Sudarsono, Heri. 2004. Bank dan Lembaga Keuangan Syariah : Deskripsi dan Ilustrasi. Edisi Dua. Yogyakarta. FE UII Ekonesia.

Suharsimi, Arikunto. 2010. Prosedur Penelitian : Suatu Pendekatan Praktik. Jakarta. PT. Rineka Cipta.

Sumitro, Warkum. 1997. Asas - Asas Perbankan Islam dan Lembaga - Lembaga Terkait (BAMUI dan Takaful) di Indonesia. Cetakan Kedua. Jakarta. PT. RajaGrafindo Persada.

Sumitro, Warkum. 2004. Asas - Asas Perbankan Islam dan Lembaga - Lembaga Terkait (BAMUI, Takaful dan Pasar Modal Syariah) di Indonesia. Jakarta. PT. RajaGrafindo Persada.

Susilo, dkk. 2000. Mengapa Memilih Bank Syariah?. Bogor. Ghalia Indonesia.

Suwardi, Endraswara. 2010. Metodologi Penelitian : Folklor, Konsep, Teori dan Aplikasi. Yogyakarta. Media Presindo.

Syafi'i Antonio, M. 2001. Bank Syariah : Dari Teori ke Praktik. Jakarta. Gema Insani Press.

Tobin, Graham A. 2009. Public Perceptions of Florida Red Tide Risk. Risk Analysis. 29 (7). pp. $963-969$.

Umam, Khotibul. 2016. Perbankan Syariah : Dasar - Dasar dan Dinamika Perkembangannya di Indonesia. Jakarta. RajaGrafindo Persada.

Undang - Undang No. 7 Tahun 1992 Tentang Perbankan.

Undang - Undang No. 10 Tahun 1998 Tentang Perubahan Undang - Undang No. 7 Tahun 1992 Tentang Perbankan.

Undang - Undang No. 21 Tahun 2008 Tentang Perbankan Syariah. 